\title{
Evaluation of Habanero Pepper (Capsicum chinense Jacq.) Varieties under Shade House Conditions in Yucatan, Mexico
}

\author{
Wilson I. Aviles-Baeza ${ }^{1}$, Mónica Guadalupe Lozano-Contreras ${ }^{1 *}$, Jorge H. Ramírez-Silva ${ }^{2}$ \\ ${ }^{1}$ Centro de Investigación Regional Sureste del Instituto Nacional de Investigaciones Forestales, Agrícolas y Pecuarias (INIFAP), \\ Mérida, Yucatán, México \\ ${ }^{2}$ Campo Experimental Mocochá del Instituto Nacional de Investigaciones Forestales, Agrícolas y Pecuarias (INIFAP), Mocochá, \\ Yucatán, México \\ Email: *lozano.monica@inifap.gob.mx
}

How to cite this paper: Aviles-Baeza, W.I., Lozano-Contreras, M.G. and Ramírez-Silva, J.H. (2021) Evaluation of Habanero Pepper (Capsicum chinense Jacq.) Varieties under Shade House Conditions in Yucatan, Mexico. Open Access Library Journal, 8: e7515. https://doi.org/10.4236/oalib.1107515

Received: May 12, 2021

Accepted: June 20, 2021

Published: June 23, 2021

Copyright $\odot 2021$ by author(s) and Open Access Library Inc.

This work is licensed under the Creative Commons Attribution International License (CC BY 4.0).

http://creativecommons.org/licenses/by/4.0/ (c) (i) Open Access

\begin{abstract}
Habanero pepper (HP) is the main emblematic horticultural species of the Yucatan Peninsula in Mexico and it is highly valuable for commercial purposes. Since the Yucatan Peninsula has been qualified by official instances with the Denomination of Origin, a very promising horizon is opened for new varieties to be demanded by the local and abroad commercial markets. Nowadays all varieties are being produced under open field conditions but its agronomic and qualified behaviour has never been evaluated under shade house production systems. Keeping in mind the foregoing, the Jaguar (Ja), Mayapán (Ma) and Calakmul $(\mathrm{Ca})$ varieties were evaluated and compared with a control, the Rey Pakal (RP) hybrid during the Fall-Winter season. A $1200 \mathrm{~m}^{2}$ shade house was used, covered with a white mesh with a density of $52 \times 25$ threads/square inch. RP and Ma reached the highest height (68.29 and $63.14 \mathrm{~cm}$ ) and stem diameter $(4.48$ and $4.46 \mathrm{~cm}$ ), compared to the rest of the evaluated varieties ( $\mathrm{Ca}$ and Ja). A greater precocity is projected in $\mathrm{Ca}$ and RP to set flower buds, flowers and fruits than in Ja and Ma. In general, flower buds setting was recorded between 23.4 and 25.6 days after transplanting (DAT), flowering was from 30.3 to $40.5 \mathrm{DAT}$ and the fruit set from 42.2 to 45.3 DAT. The four genetic materials had a similar behavior in terms of phenology. RP (hybrid) and Ma (Variety) showed the higher yields.
\end{abstract}

\section{Subject Areas}

Agricultural Engineering

\section{Keywords}

Phenology, Fruit Set, First Class Fruits, Denomination of Origin 


\section{Introduction}

Habanero pepper (HP) (Capsicum chinense Jacq.) is one of the commercial horticultural crops of the greatest culinary, social and economic importance in $\mathrm{Yu}$ catan Peninsula (YP), Mexico [1] [2]. This crop has a great regional importance in the state of Yucatán mainly because of its Denomination of Origin so called "Chile Habanero de la Península de Yucatán" (Official Gazette of the Federation [DOF], 2008) [3].

This distinction is due to the climatic (sub-humid (Aw) [4], edaphic [5] and anthropogenic conditions prevailing in the $\mathrm{YP}$, which allows the habanero pepper to guarantee its authenticity, quality control and identification of the product throughout the world, focusing mainly on its capsaicinoid content [6]. The HP is a proper crop produced mainly in Yucatán, Mexico, and its pungency ranges between 100,000 and 300,000 Scoville Units (SHU), presenting different colors and shades such as, dark green, orange-red and red when it is fully mature [7] [8].

Since the Denomination of Origin was granted by the Mexican Institute of Industrial Property (IMPI), there has been an increase in the demand of fruits for both fresh and industry market [9]. At the same time, new varieties are constantly demanded in order to satisfy all quality requirements requested by the same Denomination of Origin, promulgated by the NOM-189-SCFI-2017 (NOM, 2017) [8]. Therefore, different varieties are to be required to preserve the characteristics of the habanero pepper from the Yucatan Peninsula such as shape, color, aroma, pungency and flavor. Some varieties generated until now are:

Jaguar. Variety created by using original native germplasm from the YP and preserved the aroma, pungency and flavor characteristics of the true HP. Its fruits are uniform, with an intense emerald green color that changes to bright orange when fully ripe, weighing 6.5 to 10 grams, making them very attractive for the fresh market. Its adaptation to clay soils is a very important advantage when compared to the current native materials and other varieties. The Jaguar variety has shown yields ranging from 18.3 to $34.4 \mathrm{t} \cdot \mathrm{ha}^{-1}$ in open field and can exceed $35 \mathrm{t} \cdot \mathrm{ha}^{-1}$ under protected greenhouse agriculture conditions [10] [11].

Mayapán. Semi-erect plant is with an average height of $80 \mathrm{~cm}$ and a canopy width of $76 \mathrm{~cm}$. The leaves are deep green, without pubescence, $11 \mathrm{~cm}$ long and $6 \mathrm{~cm}$ wide. The fruits are emerald green when ripe and turn orange when ripe. The fruits have triangular shape and highly demanded by the local, national and international market. Flowering begins at 80 to 85 days after sowing (DAS) and the first harvesting starts at 120 to 125 after sowing. Under open field conditions 24 to $26 \mathrm{t} \cdot \mathrm{ha}^{-1}$ has been registered while under protected conditions yields exceed $30 \mathrm{t} \cdot \mathrm{ha}^{-1}$. The pungency exceeds 300 thousand Scoville Units when HP is properly managed with irrigation and fertilization. The Mayapán variety is well adapted to the YP (Yucatan, Campeche, Quintana Roo states) and Tabasco state [12] [13].

Calakmul. Variety with light green fruits when immature and deep red at ri- 
pening. Flowering starts from 85 to 90 DAS and harvesting at 120 to 125 DAS. It has recorded a potential yield of 25 - $30 \mathrm{t} \cdot \mathrm{ha}^{-1}$ under field conditions and $35-45$ $\mathrm{t} \cdot \mathrm{ha}^{-1}$ under closed protected environments (shade house, greenhouse). It has a compact and dichotomous growth habit with 70 to $90 \mathrm{~cm}$ tall and good foliage coverage. Leaves are light Green, $13.5 \mathrm{~cm}$ long and $7.7 \mathrm{~cm}$ wide presenting a distinctive characteristic such as anthocyanins in nodes midribs of the leaves. The fruits are triangular-bell shaped with a 5.2 to $6.1 \mathrm{~cm}$ long, 3.3 to $4.1 \mathrm{~cm}$ wide, in diameter. weighing from 15 to $20 \mathrm{~g}$. The Calakmul variety is well adapted to the YP (Campeche, Quintana Roo, Yucatán) and Tabasco state [12] [13].

Although these HP varieties were originally generated for open field production it was important to evaluate their agronomic and quality behavior under well protected and controlled conditions since the YP has been facing an important growth in greenhouses and shade net houses during the last decades.

\section{Materials}

The study was carried out at the facilities of "San Arturo Greenhouses Company" located in Santa Clara farm, municipality of Chicxulub Pueblo in the state of Yucatán, Mexico ( $21^{\circ} 08^{\prime} 13^{\prime \prime}$ North Latitude and $89^{\circ} 30^{\prime} 35^{\prime \prime}$ West Longitude) at 8 meters above sea level.

\subsection{The Shade House and Used Soils}

A $1200 \mathrm{~m}^{2}$ shade house was used, covered with a white-glass mesh with a density of $52 \times 25$ threads/square planting on a stony soil classified as Tzek el according to the Mayan classification or lithic Leptosol according to the World Reference Base for Soil Resources (WRBSR) [14].

\subsection{Varieties of Habanero Pepper}

Three habanero pepper varieties: Jaguar (Ja), Mayapán (Ma) and Calakmul (Ca) from creole germplasm and a hybrid named Rey Pakal (RP) from a Transnational Company, as a control were used as treatments which are being shown in Table 1.

All HP peppers are adapted to the climatic, edaphic and anthropogenic conditions prevailing in the YP, which allow the HP to guarantee its authenticity and

Table 1. Habanero Pepper genetic materials evaluated under shade house conditions.

\begin{tabular}{cccc}
\hline \multirow{2}{*}{ Material } & \multicolumn{3}{c}{ Capsicum chinense Jacq. } \\
\cline { 2 - 4 } & Category & Color at ripening & Origin \\
\hline Rey Pakal (RP) & Hybrid & Dark Green and Red & US Agriseeds \\
Calakmul (Ca) & Variety & Light Green and Red & INIFAP $^{*}$ \\
Jaguar (Ja) & Variety & Dark Green and Orange & INIFAP \\
\hline
\end{tabular}

*INIFAP (Instituto Nacional de Investigaciones Forestales, Agrícolas, y Pecuarias). 
capsaicinoid content demanded by the Denomination of Origin of the Mexican Institute of Industrial Property (IMPI).

However, different new varieties are to be required for further evaluation in order to preserve the characteristics of the HP from the YP such as shape, color, aroma, pungency and flavor.

\section{Methods}

\subsection{Transplanting, Irrigation and Fertilizers Used}

Transplanting was carried out during the month of October and plants were irrigated every day, applying insecticides and fungicides for pests and diseases control. After transplanting, fertigation was used applying the formula of fertilization: 100-100-100 of Nitrogen $(\mathrm{N})$, Phosphorus $\left(\mathrm{P}_{2} \mathrm{O}_{5}\right)$ and Potassium $\left(\mathrm{K}_{2} \mathrm{O}\right)$ respectively complemented with foliar fertilizers based on a mixture of $\mathrm{N}, \mathrm{P}_{2} \mathrm{O}_{5}$, and $\mathrm{K}_{2} \mathrm{O}$ and micronutrients ( $\mathrm{Fe}, \mathrm{Mn}, \mathrm{Zn}, \mathrm{B}, \mathrm{Cu}$ and $\mathrm{Mo}$ ) using, as a source of nutrients, the fertilizer 19-19-19 + Micronutrients ones a week.

\subsection{Measured Variables in Genetic Materials}

The following variables were recorded considering six plants per replication:

Plant height $(\mathrm{cm})$. Measured with a metallic field ruler from the base of the stem to the highest leaf at 15 and 45 days after transplanting (DAT). Stem diameter $(\mathrm{mm})$, recorded 15 and $45 \mathrm{DAT}$, with a Vernier, in the base of the main stem, two centimeters above the ground.

Phenology. Starting at 15 DAT, the number of flower buds, opened flowers and fruits set per plant was recorded every two days until $100 \%$ of the plants showed all those phenological stages. In this way, the sampling time was twice as long as that recommended by Garruña-Hernández et al., (2012) [15] who indicate that $50 \%+1$ of plants is a sufficient sample to properly evaluate flowering and fructification stages in this kind of experiments.

Yield $\left(\mathrm{t} \cdot \mathrm{ha}^{-1}\right)$. The accumulated fruit weight of 32 plants was recorded during 11 weekly pickings, with a $50 \mathrm{~kg}$ capacity Ohaus scale. The fruits were classified by quality as follows: first-class fruits with more than $6.5 \mathrm{~g}$; second-class fruits weighing between 5.5 and $6.4 \mathrm{~g}$ and third-class fruits with less than $5.4 \mathrm{~g}$ [16].

\subsection{Experimental Design and Statistical Method of Analysis}

The experiment was evaluated using a Randomized Complete Block Design with four replications. Each variety was established in experimental units consisting of 4 irrigation lines of $5 \mathrm{~m}$ long, $2.0 \mathrm{~m}$ apart from each other and 64 plants per plot (plants $0.3 \mathrm{~m}$ apart from each other) equivalent to a population density of 16,666 plants $\mathrm{ha}^{-1}$. To evaluate the genetic materials, only the two central lines were harvested considering 32 plants per plot.

The data were submitted to an Analysis of Variance (ANOVA) in order to determine whether there are or not statistically significant differences among treatments considering the resulted means of the measured parameters. 
In the case of significant differences among treatments a Tukey's range test was used as a complement of ANOVA as a discriminatory test capable to find specific means that are significantly different from each other.

\section{Results and Discussion}

\subsection{Plant Height in Genetic Materials and Statistical Differences}

Capsicum chinense is an annual cycle plant and it can reach 12 months depending on the agronomic management; its height is variable, ranging from 75 to 120 centimeters under greenhouse conditions [17]. In this work, highly significant statistical differences $(\mathrm{p} \leq 0.01)$ were observed among varieties at both 15 and 45 DAT (Table 2).

The RP hybrid and Ja and Ma varieties registered the highest height in both evaluations with values ranging from 23.14 to $28.24 \mathrm{~cm}$ at $15 \mathrm{DAT}$ and from 59.64 to $68.29 \mathrm{~cm}$ at 45 DAT being statistically similar. The Ca variety showed the lowest height with $20.38 \mathrm{~cm}$ at 15 DAT and $53.39 \mathrm{~cm}$ at 45 DAT being statistically different as compared to RP but similar to Ja and Ma.

All varieties did not reach their maximum height potential which may be due to the low light intensity that normally occurs under greenhouse conditions [18] and that additionally the register of this variable was made in a very short period of time (15 and $45 \mathrm{DAT}$ ) in the month of October, in a season with a low light intensity (Fall season).

It has been documented that the potential height for Ja variety ranged from 80 to $90 \mathrm{~cm}$ under open field conditions and up to $1.8 \mathrm{~m}$ under in protected agriculture systems (macro-tunnels and greenhouse) with tutoring [11]. In the case of the semi-erect $\mathrm{Ma}$ variety, an average height of $80 \mathrm{~cm}$ has been reported whilst for the $\mathrm{Ca}$, with dichotomous growth habit, its height ranged from 70 to $90 \mathrm{~cm}$ with good canopy development [19].

\subsection{Stem Diameter at 15 and 45 DAT}

No significant statistical differences were found for stem diameters among materials. There was an overall average increase of $4.24 \mathrm{~cm}$ from the first recorded diameter, at $15 \mathrm{DAT}$, to the second one at $45 \mathrm{DAT}$. The hybrid RP and Ma variety

Table 2. Height $(\mathrm{cm})$ of different Habanero pepper genetic materials at 15 and 45 DAT under shade house conditions in Yucatan. Mexico.

\begin{tabular}{ccc}
\hline \multirow{2}{*}{ Material } & \multicolumn{2}{c}{ Capsicum chinense Jacq. } \\
\cline { 2 - 3 } & $15 \mathrm{DAT}$ & $45 \mathrm{DAT}$ \\
\hline Rey Pakal & $28.24 \mathrm{a}$ & $68.29^{\mathrm{a}}$ \\
Calakmul & $20.38 \mathrm{~b}$ & $53.39 \mathrm{~b}$ \\
Jaguar & $23.90 \mathrm{ab}$ & $59.64 \mathrm{ab}$ \\
Mayapán & $23.14 \mathrm{ab}$ & $63.14 \mathrm{ab}$ \\
\hline
\end{tabular}

Rey Pakal (RP), Calakmul (Ca), Jaguar (Ja), Mayapán (Ma). Different letters indicate highly significant statistical differences between materials by Tukey $(\mathrm{p} \leq 0.01)$ 
showed to be 4.48 and $4.46 \mathrm{~mm}$ respectively (Table 3 ), whilst the Ja variety had the lowest average with $3.78 \mathrm{~mm}$.

\subsection{Flowering Behavior as a Plant Phenology of Genetic Materials}

No statistical differences were detected in phenology, although Ca and RP showed earlier flower buds, flowering and fruit set than Ja and Ma. Considering all genetic materials, the emission of flower buds ranged from 23.4 and 25.6 DAT, flowers opening from 38.3 to $40.5 \mathrm{DAT}$ and fruit set from 42.2 to 45.3 (DAT) (Table 4). The flowering data are similar to those reported by Hernández-Pinto et al. (2020) [2], who mentioned that the Ma variety begins flowering at approximately 45 DAT. Ramirez-Meraz et al., 2018 [11] have mentioned 70 to 85 DAT for the flowering of Ja variety; or 25 and 40 DAT consistent with Table 4.

On the other hand, Garruña-Hernández et al., 2012 [15], reported that flowering of $\mathrm{HP}$ can be delayed at temperatures above $35^{\circ} \mathrm{C}$ and even inhibited above $40^{\circ} \mathrm{C}$, which occurs during the Spring-Summer season in the state of $\mathrm{Yu}$ catan, Mexico. The optimum temperature for HP, in Yucatan, occurs during the Fall-Winter season, when temperatures range from $24^{\circ} \mathrm{C}$ to $28^{\circ} \mathrm{C}$ [20].

\subsection{Behavior of Fruit Set in Genetic Materials and Statistical Differences}

The analysis of variance showed highly significant differences $(p \leq 0.01)$ in the

Table 3. Diameter of Habanero pepper stems (mm) at 15 and 45 DAT under shade house conditions in Yucatan, Mexico.

\begin{tabular}{cccc}
\hline & \multicolumn{3}{c}{ Capsicum chinense Jacq. } \\
\cline { 2 - 4 } Material & 15 DAT & 45 DDT & INC * $^{*}$ \\
Rey Pakal & $3.61^{*}$ & 8.09 & 4.48 \\
Calakmul & 3.81 & 8.02 & 4.21 \\
Jaguar & 3.44 & 7.22 & 3.78 \\
Mayapán & 3.69 & 8.15 & 4.46 \\
Average & 3.63 & 7.87 & 4.24 \\
\hline
\end{tabular}

${ }^{*} \mathrm{INC}=$ Diameter Increment.

Table 4. Phenology of Habanero pepper genetic materials grown under shade house conditions in Yucatan, Mexico.

\begin{tabular}{cccc}
\hline \multirow{2}{*}{ Material } & \multicolumn{3}{c}{ HP Capsicum chinense Jacq. } \\
\cline { 2 - 4 } & DAFB & DAOF & DAFRUT \\
\hline Rey Pakal & $24.2^{*}$ & 38.3 & 42.2 \\
Calakmul & 23.4 & 38.8 & 44.3 \\
Jaguar & 25.2 & 40.5 & 45.3 \\
Mayapán & 25.6 & 40.3 & 45.2 \\
\hline
\end{tabular}

${ }^{\star}$ NS $=$ No Significant Differences. DAFB: Days to Flower Buds; DAOF: Days to Flowering; DAFRUT: Days to Fruit Set. 
number of fruit set before harvesting (61 DAT). The results are shown in Figure 1 ; the best material was the hybrid RP with 38.5 fruits, although it does not differ statistically from Ja and Ma with 30.88 and 28 fruit set per plant, respectively. Ca was the variety with the lower number of fruit set (20.58) and it was the only variety statistically different from the hybrid RP. It can be observed (Figure 1) that RP, Ja and Ma showed better fruit set capacity, occurring from 16 to 19 days, just after detecting the first fruit set from all materials (Table 4).

\subsection{Yield ( $\left.\mathrm{t} \cdot \mathrm{ha}^{-1}\right)$ in Genetic Materials and Statistical Analysis}

According to ANOVA, highly significant differences $(\mathrm{p} \leq 0.01)$ were found for both total accumulated yield (tha ${ }^{-1}$ ) and the first class yield. The RP hybrid (Control) had the higher yield with 25.32 and 23.46 tha $^{-1}$ respectively. On the other hand, Ja yielded 22.29 and $20.11 \mathrm{t} \cdot \mathrm{ha}^{-1}$ and Ma 25.17 and $22.73 \mathrm{t} \cdot \mathrm{ha}^{-1}$, respectively. Ca was the variety with significantly lower yield with 13.21 and 11.71 t.hat ${ }^{-1}$ (Figure 2).

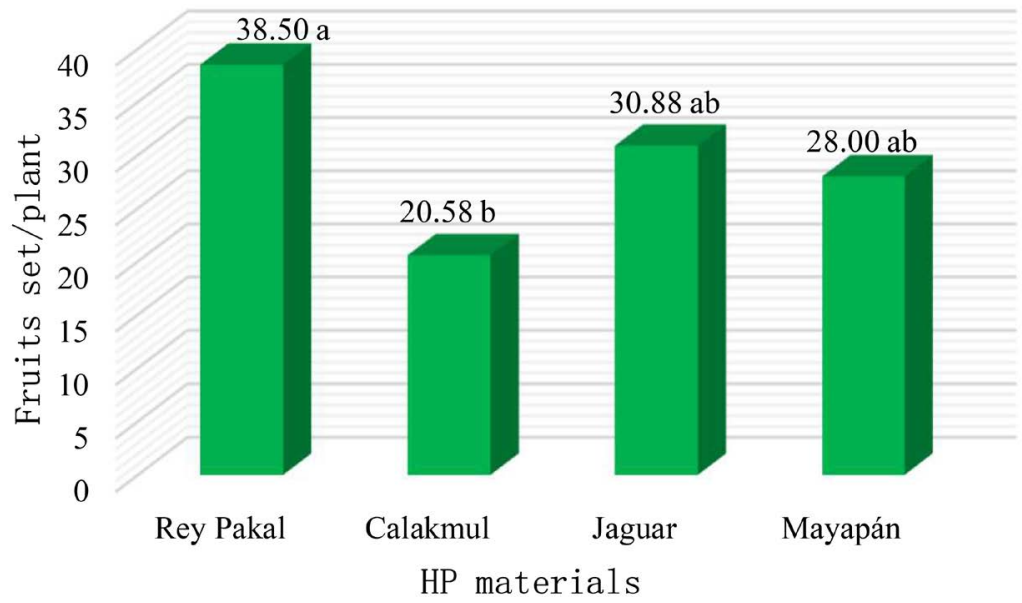

Figure 1. Number of fruit set at 61 DAT for Habanero Pepper materials evaluated under shade house conditions (Different letters means statistical differences according to Tukey's test $(\mathrm{p} \leq 0.05))$.

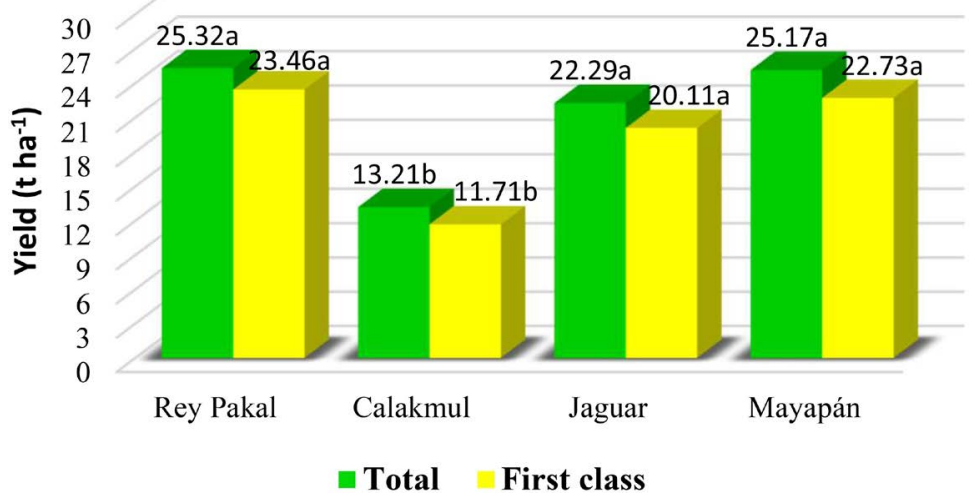

Figure 2. Accumulated Total yield $\left(\mathrm{t} \cdot \mathrm{ha}^{-1}\right)$, (in green bars) and yield ( $\mathrm{t} \cdot \mathrm{ha}^{-1}$ ) of First class quality fruits, (in yellow bars), after eleven harvests of different Habanero Pepper genetic materials. 
Coronado Navarro, 2017 [21], has reported yields of 31.9 t/ha for Ma variety whilst for the Ja variety very good yields (around $15 \mathrm{t} \cdot \mathrm{ha}^{-1}$ ), have been achieved under good rainfall conditions in South-Central area of the Mexican states of Veracruz, Campeche and Chiapas, or when irrigation with medium or high technology is applied. Under field conditions, using drip irrigation and fertigation systems, yields of Ja variety can be up to $30 \mathrm{t} \cdot \mathrm{ha}^{-1}$ and even higher than 43 t.ha ${ }^{-1}$ under protected closed systems. In the same production systems, local commercial HP varieties and the HP native ones have shown yields from 10.8 to $26.5 \mathrm{t} \cdot \mathrm{ha}^{-1}$ and $12-21.7 \mathrm{t} \cdot \mathrm{ha}^{-1}$ respectively [11].

In the case of Ca variety, yields of $15 \mathrm{t} \cdot \mathrm{ha}^{-1}$ have been reported in open field conditions and from 25 to $29 \mathrm{t} \cdot \mathrm{ha}^{-1}$ in shade house systems whilst the yields of Ma have been documented to be $30 \mathrm{t} \cdot \mathrm{ha}^{-1}$ under open field conditions [19].

\section{Conclusions}

The study showed that all genetic materials, including the hybrid as the control, regardless of their genetic origin, lasted the same phenological stages and no differences were found in the development of stems.

However, other variables such as plant height, fruit set capacity and yield, were more sensitive to genetic differences since the Mayapan and Jaguar varieties had the most outstanding behavior even the same as the Rey Pakal hybrid, under shade house conditions, in the north of Yucatán State.

The foregoing is a remarkable finding since it is always expected that the hybrids should be superior than the varieties due to the hybrid vigor expression. On the other hand, it is important to point out that the cost of seeds for sowing, of all varieties, is currently nine to ten times lower than the hybrids so better profitability is expected with the varieties.

\section{Acknowledgements}

We thank the National Institute of Forestry, Agricultural and Livestock Research (INIFAP), for financing this work as part of the project called: Genetic Improvement of Chile Habanero in Yucatán, Project number "1053510019”.

\section{Conflicts of Interest}

The authors declare no conflicts of interest regarding the publication of this paper.

\section{References}

[1] López-Puc, G., Rodríguez-Rodríguez, J.D., Ramírez-Sucre, M.O. and Rodríguez Buenfil, I.M. (2020) Agronomic Management and Factors Influencing the Growth and Development of Habanero Pepper Crop. In: Buenfil, I.M.R. and Manuel, O.R.S., Eds., Metabolomics and Cultivation of the Habanero Pepper (Capsicum chinense Jacq) from the Yucatan Peninsula, Center for Research and Technology Assistence and Design of the State of Jalisco A.C. CIATEJ. Guadalajara Jalisco, 4-26. https://ciatej.repositorioinstitucional.mx/jspui/handle/1023/714 
[2] Hernández-Pinto, C., Garruña, R., Andueza-Noh, R., Hernández-Nuñez, E., Zavala-León, M.J. and Pérez-Gutiérrez, A. (2020) Post-Harvest Storage of Fruits: An Alternative to Improve Physiological Quality in Habanero Pepper Sedes. Magazine Bio Ciencias, 7, e796.

http://revistabiociencias.uan.edu.mx/index.php/BIOCIENCIAS/article/view/796/66 $\underline{4}$

[3] Official Gazette of the Federation [DOF] (2008) General Declaration of the Denomination of Origin Protection Habanero Pepper from Yucatán. http://dof.gob.mx/nota detalle.php?codigo $=5063633 \&$ fecha $=10 / 10 / 2008$

[4] Vidal Zepeda, R. (2005) Yucatan Peninsula. Region 11. The Climatic Regions of Mexico. Selected Topics. Collection of Geography of Mexico (Ed.). In Institute of Geography. National Autonomous University of Mexico (UNAM), Mexico, 189-204. http://www.publicaciones.igg.unam.mx/index.php/ig/catalog/view/42/42/128-1

[5] Bautista, F., Palma-López, D., Huchin-Malta, W. (2005) Update of the State of Yucatan Soils Classification. In: Bautista, F. and Palacio, G., Eds., Characterization and Management of the Yucatan Peninsula Soils: Agricultural, Forestry and Environmental Implications, Autonomous University of Campeche, Autonomous University of Yucatán, National Institute of Ecology, Mérida, 105-122.

https://www.researchgate.net/publication/313757781 Actualizacion de la clasifica cion de los suelos del estado de Yucatan

[6] Cuevas-Glory, L.F., Sosa-Moguel, O., Pino, J. and Sauri-Duch, E. (2015) GC-MS Characterization of Volatile Compounds in Habanero Pepper (Capsicum chinese Jacq.) by Optimization of Headspace Solid-Phase Microextraction Conditions. Food Analytical Methods, 8, 1005-1013. https://doi.org/10.1007/s12161-014-9980-x https://link.springer.com/article/10.1007/s12161-014-9980-x

[7] Pino, J., Sauri-Duch, E. and Marbot, R. (2006) Changes in Volatile Compounds of Habanero Chile Pepper (Capsicum chinense Jack. Cv. Habanero) at Two Ripening Stages. Food Chemistry, 94, 394-398.

https://doi.org/10.1016/j.foodchem.2004.11.040

https://www.sciencedirect.com/science/article/abs/pii/S0308814604008635?via\%3Di $\underline{\text { hub }}$

[8] Official Mexican Standard (2017) NOM-189-SCFI-2017. Habanero Pepper from the Yucatan Peninsula (Capsicum chinense Jacq.). Specifications and Test Methods. http://www.dof.gob.mx/nota detalle popup.php?codigo $=5513923$

[9] Zavala, M.J., López, A., Santamaría, F. and Baeza, J.J. (2013) Quality of Habanero Pepper (Capsicum chinense Jacq.) Seeds through Postharvest Fruits Conditioning. Memories at 10th World Pepper Convention, Durango, Mexico, 282-287.

[10] Ramírez Meraz, M., Arcos Cavazos, G., Mata Vázquez, H., Vázquez García, E. and Méndez Aguilar, R. (2015) Varieties and Hybrids of Peppers and Their Management for Southern Tamaulipas. Las Huastecas Experimental Field Station. Technical Brochure No. MX-0-310701-11-03-14-09-40, 48 p.

https://docplayer.es/62689342-Variedades-e-hibridos-de-chile-para-el-sur-de-tama ulipas.html

[11] Ramírez Meraz, M., Arcos Cavazos, G. and Méndez Aguilar, R. (2018) Jaguar: A Variety of Habanero Pepper for Mexico. Mexican Journal of Agricultural Sciences, 9, 487-492. https://doi.org/10.29312/remexca.v9i2.1089 https://cienciasagricolas.inifap.gob.mx/editorial/index.php/agricolas/article/view/10 $\underline{89}$

[12] National Institute of Forestry, Agricultural and Livestock Research (INIFAP) (2018) INIFAP Products and Services. Seed. Jaguar Habanero Pepper. 
https://vun.inifap.gob.mx/PortalWeb/ DetalleProducto

[13] Ramírez Meraz, M., Arcos Cavazos, G., Méndez Aguilar, R., Meneses Márquez I. (2019) Varieties and Hybrids of Chili for the Mexican Tropics. In: Meza Villalvazo, V.M. and Chay Canul, A.J., Eds., Agricultural Production: An Integrated Approach, University of Papaloapan, Loma Bonita Oaxaca, 29-38.

https://www.unpa.edu.mx/libros/11 Libro Produccion Agropecuaria.pdf

[14] Baustista, F. and Zinck, J.A. (2010) Construction of Yucatec Maya Soil Classification and Comparison with the WRB Frame Work. Journal of Ethnobiology and Ethnomedicine, 6, Article No. 7. https://doi.org/10.1186/1746-4269-6-7 https://ethnobiomed.biomedcentral.com/articles/10.1186/1746-4269-6-7

[15] Garruña-Hernández, R., Canto, A., Mijangos-Cortés, J.O., Islas, I., Pinzón, L. and Orellana, R. (2012) Changes in Flowering and Fruiting of Habanero Pepper in Response to Higher Temperature and $\mathrm{CO}_{2}$. Journal of Food, Agriculture \& Environment, 10, 802-808. https://www.wflpublisher.com/Abstract/3516

[16] Borges-Gómez, L., Cervantes Cárdenas, L., Ruiz Novelo, J., Soria Fregoso, M., Reyes Oregel, V. and Villanueva Couoh, E. (2010) Capsaicinoids in Habanero Pepper (Capsicum chinense Jacq.) under Different Conditions of Humidity and Nutrition. Terra Latinoamericana, 28, 35-41.

http://www.scielo.org.mx/scielo.php?script=sci arttext\&pid=S0187-5779201000010 $\underline{0004 \& \ln g=\mathrm{es} \& \ln g=\mathrm{es}}$

[17] Ruiz-Lau, N., Medina Lara, F. and Martínez Estévez, M. (2011) The Habanero Pepper: Origin y Uses. Science, 70-77.

https://www.amc.edu.mx/revistaciencia/images/revista/62 3/PDF/Habanero.pdf

[18] Ramírez-Luna, E., Castillo-Aguilar, C. C., Aceves-Navarro, E., Carrillo-Ávila, E. (2005) Effect of Products with Growth Regulators on Flowering and Fruit Set in 'Habanero' Chili. Revista Chapingo Serie Horticultura, 11, 93-98.

https://revistas.chapingo.mx/horticultura/?section=articles\&subsec=issues\&numero $\equiv$ 7\&articulo $=135$

[19] Tut, P.F.J., Santamaría, B.F., Zavala, L.M.J. and Berny, M.T.J.C. (2013) Characteristics of Improved Habanero Pepper Materials for the Yucatan Peninsula. National Institute of Forestry, Agricultural and Livestock Research. Mocochá Experimental Field Station. Southeast Regional Research Center, Merida, Yucatan, 38 p.

https://docplayer.es/67554574-Caracteristicas-de-materiales-mejorados-de-chile-ha banero-para-la-peninsula-de-yucatan.html

[20] Ramírez-Jaramillo, G. and Lozano-Contreras, M.G. (2018) Potential Areas for the Establishment of Habanero Pepper (Capsicum chinense Jacq.) under Irrigation in the Yucatan Peninsula. Journal: Center of Graduates and Research. Technological Institute of Merida, 33, 85-90.

http://www.revistadelcentrodegraduados.com/2019/12/areas-potenciales-para-el.ht $\underline{\mathrm{ml}}$

[21] Coronado Navarro, J.H. (2017) Evaluation of Native Microorganisms in the Habanero Pepper (Capsicum chinense Jacq.) under Organic Cultivation. Thesis for the Degree of Master Science in Tropical Horticulture, Conkal Technological Institute. Conkal, Yucatán, 19 p.

http://www.itconkal.edu.mx/images/POSGRADO NEW/GEN 2015-2017/Juan\%20 Humberto\%20Coronado\%20Navarro.pdf 